\title{
Role of Vibrational Spectroscopy in Stem Cell Research
}

\author{
Ceren Aksoy ${ }^{1}$ and Feride Severcan ${ }^{2}$ \\ ${ }^{1}$ Department of Biotechnology, Middle East Technical University, 06800 Ankara, Turkey \\ ${ }^{2}$ Department of Biological Sciences, Middle East Technical University, 06800 Ankara, Turkey
}

Correspondence should be addressed to Feride Severcan, feride@metu.edu.tr

Copyright (C) 2012 C. Aksoy and F. Severcan. This is an open access article distributed under the Creative Commons Attribution License, which permits unrestricted use, distribution, and reproduction in any medium, provided the original work is properly cited.

\begin{abstract}
Recent researches have mainly displayed the significant role of stem cells in tissue renewal and homeostasis with their unique capacity to develop different cell types. These findings have clarified the importance of stem cells to improve the effectiveness of any cell therapy for regenerative medicine. Identification of purity and differentiation stages of stem cells are the greatest challenges of stem cell biology and regenerative medicine. The existing methods to carefully monitor and characterize the stem cells have some unwanted effects on the properties of stem cells, and these methods also do not provide real-time information about cellular conditions. These challenges enforce the usage of nondestructive, rapid, sensitive, high quality, label-free, cheep, and innovative chemical monitoring methods. In this context, vibrational spectroscopy provides promissing alternative to get new information into the field of stem cell biology for chemical analysis, quantification, and imaging of stem cells. Raman and infrared spectroscopy and imaging can be used as a new complimentary spectroscopic approaches to gain new insight into stem cell reseaches for future therapeutic and regenerative medicines. In this paper, recent developments in applications of vibrational spectroscopy techniques for stem cell characterization and identification are presented.
\end{abstract}

Keywords: Raman spectroscopy, Raman microspectroscopy, infrared spectroscopy, infrared microspectroscopy, embryonic stem cells, adult stem cells, mesenchymal stem cells

\section{Introduction}

Stem cells are unspecialized cells with an ability to renew themselves through cell division and they can be induced to differentiate specific cell types of different tissues and organs. Stem cells may be isolated from embryos, umbilical cords, and adult tissues, and the plasticity of a stem cell varies depending on where they originate from [9, 10]. Embryonic stem cells (hESCs) are derived from the inner cell mass of fertilized embryos. They have two main characteristics which are the ability to proliferate without differentiation by a process of self-renewal and the potential to differentiate into specialized cell types by an induction. These characteristics are very important for regenerative medicine [11]. Adult human stem cells can be derived from a wide variety of tissues and they have the ability to "regenerate" cell types found in their specific local environment. They can be hematopoietic or mesenchymal stem cells. Hematopoietic stem cells are found in peripheral blood and bone marrow, and they generate blood cells required for daily blood turnover. Hematopoietic stem cells have been used in transfusion medicine 
for decades to treat blood disorders. Mesenchymal stem cells are nonhematopoietic and they have the potential to differentiate into specific lineages that are mainly chondrocytes, osteoblasts, adipocytes, fibroblasts, marrow stroma, and other tissues of mesenchymal origin [12-14]. There has been an increasing demand on therapeutic usage of stem cells in regenerative medicine over the last few years. Such an increasing interest makes it inevitable to solve existing challenges pertaining to isolation, identification, enrichment and purification of stem cells for the success of future clinical applications $[15,16]$. Routinely used biological assays to analyze stem cells involve fixation, staining, and drying steps that destroy cellular characteristics, and cannot provide real-time information about natural life process of the cells [17]. The unique characteristic of stem cells that are assigned with reliable and definitive reproducible markers have to be clearly identified by noninvasive techniques. Therefore, the development and application of new methods capable of nondestructively collecting high-quality, realtime chemical information from living human stem cells have been enforced [17]. From this point, the correlation of conventional methods with vibrational spectroscopy to probe biochemical and biophysical changes associated with stem cell characteristics becomes interesting field [18]. Raman and infrared (IR) spectroscopy have gained great interest to elucidate unique optical markers for identifying stem cell populations, their cell lineages, and the degree of their maturation and differentiation as a noninvasive, nondestructive, and label-free methods [15, 19].

\section{Vibrational Spectroscopy with Sampling Methods in Stem Cell Researches}

\subsection{Fourier Transform Infrared (FTIR) Spectroscopy}

Fourier transform infrared (FTIR) spectroscopy is a powerful technique to obtain the molecular fingerprint of a sample which absorbs the IR wave according to chemical bonds of its molecules. The type of the bonds and the strength of the intermolecular interactions with well-defined vibrational frequencies produce a specific biochemical and biophysical fingerprint of the sample when they interact with IR ligth [20,21]. Therefore, IR spectra of the sample with its complex molecular vibrational modes provide an information about specific structure of biomolecules. Band assignments of IR spectra of human cell lines are presented in Table 1, according to different publications in the literature. MidIR spectroscopy, which is more frequently used in stem cell research, uses radiation in the region of $4000-400 \mathrm{~cm}^{-1}$. Two types of vibrations are observed in this region [22]. These are called as stretching and bending vibrations. Stretching vibrations involve bond-length changes, while bending vibrations involve changes in bond angles. According to the Beer-Lambert Law, the intensities of the IR bands are proportional to the concentrations of the macromolecules in sample [20, 23]. One of the major issue when performing infrared measurements in the mid-infrared region is the strong background signal of water. Since the signal of water interfere with the spectra of biological sample, the water background has to be subtracted to obtain final spectra. This problem has been solved with the development of Fourier transform infrared (FTIR) spectrometers which provides digital subtraction of water bands. In general application procedure, in addition to automatic subtraction, the mild drying of biological samples with $\mathrm{N}_{2}$ gas eliminates the excess of water from the system. Synchrotron FTIR imaging with its high signalto-noise ratio produce high resolution for single-cell measurements. Attenuated total reflection (ATR)FTIR spectroscopic imaging of single cells can be acquired rapidly enough to perform imaging within a few minutes on live cells by minimizing the effective path length of the IR light in the sample [24, 25]. 
Table 1: IR spectroscopy band assignments of human cells [1-4].

\begin{tabular}{|c|c|}
\hline $\begin{array}{l}\text { Wavenumber } \\
\left(\mathrm{cm}^{-1}\right)\end{array}$ & Assignment \\
\hline 3328 & $\begin{array}{l}\text { Amide } \mathrm{A}: \mathrm{N}-\mathrm{H} \text { and } \mathrm{O}-\mathrm{H} \text { stretching vibrations of polysaccharides, } \\
\text { proteins }\end{array}$ \\
\hline 3129 & Amide $\mathrm{B}$ : $\mathrm{N}-\mathrm{H}$ stretching vibrations of proteins \\
\hline 3015 & Olefinic $=\mathrm{CH}$ stretching: unsaturated lipids, cholesterol esters \\
\hline 2960 & $\mathrm{CH}_{3}$ antisymmetric stretching: lipids, protein side chains \\
\hline 2920 & $\mathrm{CH}_{2}$ antisymmetric stretching: mainly lipids \\
\hline 2875 & $\mathrm{CH}_{3}$ symmetric stretching: protein side chains, lipids \\
\hline 2850 & $\mathrm{CH}_{2}$ symmetric stretching: mainly lipids \\
\hline $1720-1745$ & $\begin{array}{l}\mathrm{C}=\mathrm{O} \text { stretching vibrations of lipids (triglycerides and cholesterol } \\
\text { esters) }\end{array}$ \\
\hline $1710-1716$ & $\mathrm{C}=\mathrm{O}$ antisymmetric stretching: RNA and purine base \\
\hline $1705-1690$ & $\mathrm{C}=\mathrm{O}$ antisymmetric stretching vibrations: $\mathrm{RNA}, \mathrm{DNA}$ \\
\hline 1654 & $\begin{array}{l}\text { Amide I: } \mathrm{C}=\mathrm{O}(80 \%) \text { and } \mathrm{C}-\mathrm{N}(10 \%) \text { stretching, } \mathrm{N}-\mathrm{H}(10 \%) \\
\text { bending vibrations: proteins a-helix }\end{array}$ \\
\hline $1630-1640$ & $\begin{array}{l}\text { Amide I: } \mathrm{C}=\mathrm{O}(80 \%) \text { and } \mathrm{C}-\mathrm{N}(10 \%) \text { stretching, } \mathrm{N}-\mathrm{H}(10 \%) \\
\text { bending vibrations:proteins } \beta \text {-structure }\end{array}$ \\
\hline 1610,1578 & $\mathrm{C}_{4}-\mathrm{C}_{5}$ and $\mathrm{C}=\mathrm{N}$ stretching in imidazole ring of DNA, RNA \\
\hline 1515 & Aromatic tyrosine ring \\
\hline $1540-1550$ & $\begin{array}{l}\text { Amide II: } \mathrm{N}-\mathrm{H}(60 \%) \text { bending and } \mathrm{C}-\mathrm{N}(40 \%) \text { stretching vibrations: } \\
\text { proteins } \alpha \text {-helix }\end{array}$ \\
\hline 1530 & $\begin{array}{l}\text { Amide II: } \mathrm{N}-\mathrm{H}(60 \%) \text { bending and } \mathrm{C}-\mathrm{N}(40 \%) \text { stretching vibrations: } \\
\text { proteins } \beta \text {-structure }\end{array}$ \\
\hline 1467 & $\mathrm{CH}_{2}$ bending vibrations: lipids and proteins \\
\hline 1455 & $\mathrm{CH}_{3}$ bending and $\mathrm{CH}_{2}$ scissoring vibrations: lipids and proteins \\
\hline $1370-1400$ & $\begin{array}{l}\mathrm{COO}-\text { symmetric stretching and } \mathrm{CH}_{3} \text { bending vibrations: lipids, } \\
\text { proteins }\end{array}$ \\
\hline $1330-1200$ & Amide III: proteins \\
\hline $1230-1244$ & $\begin{array}{l}\mathrm{PO}_{2}^{-} \text {antisymmetric stretching vibrations: RNA, DNA and } \\
\text { phospholipids }\end{array}$ \\
\hline $1090-1080$ & $\mathrm{PO}_{2}{ }^{-}$symmetric stretching vibrations: RNA, DNA \\
\hline 1060,1050 & $\mathrm{C}-\mathrm{O}$ stretching vibrations: deoxyribose/ribose DNA, RNA \\
\hline 996 & RNA stretch and bend ring of uracil \\
\hline 965 & $\begin{array}{l}\mathrm{PO}_{4}^{-} \text {symmetric stretch (DNA) and deoxyribose-phosphate skeletal } \\
\text { motions }\end{array}$ \\
\hline $925-929$ & Sugar vibrations in backbone of DNA-Z form \\
\hline
\end{tabular}




\subsection{Raman Spectroscpoy}

Raman spectroscopy is based on inelastic scattering of monochromatic light during which the frequency of photons in monochromatic light slightly changes upon an interaction with a sample at vibrational level. This is called as Raman effect which is a low probability event since resonance conditions are not fulfilled with incident radiation. When Raman Effect is produced by frequency shifts of re-emitted photons, an information about vibrational, rotational, and other low frequency transitions in molecules is obtained. Molecular fingerprinting is achieved and quantitative information can be acquired from the spectrum of sample through the number of molecular bonds that are present $[16,26,27]$. Since Raman spectroscopy has bands with very low intensity values and its investigation requires high-quality instrumentation and high signal-to-noise ratios to identify subtle spectral differences. Raman signals and the intensity of bands is enhanced by special techniques such as resonance Raman spectroscopy, surface-enhanced Raman spectroscopy (SERS), and coherent anti-Stokes Raman spectroscopy. All these techniques are very suitable for single-cell studies, because single cells are very appropriate for Raman spectroscopy with their high concentration biomolecules in their condensed volume. Data acquisition of single cells and their subcellular organelles require coupling of Raman spectrometers with microscopes that provide two main advantages. One of the advantage is achieving lateral resolutions up to the Abbe's limit of diffraction below $1 \mu \mathrm{m}$. High axial resolutions are obtained by confocal microscopes. Second advantage is achieving maximum sensitivity with a maximum photon flux of laser beam onto the sample and the maximum collection of scattered photons from the sample [20,28]. Briefly, Raman microscopy can either be operated in a point-detection mode, scanning of wide field mode with its high spatial resolution and signal-to-noise ratio enable the single cells to collect their spectra from focal volumes smaller than $1 \mu \mathrm{m}$ [29]. As a conclusion, Raman spectroscopy with its nondestructivity using visible or near-infrared wavelengths for excitation can be applied under in vivo conditions without staining or other markers in order to monitor inherent vibrational properties of biomolecules in the cells. Raman imaging of cells complementary with analytical methods in cell biology like electron microscopy, fluorescence microscopy, and autoradiography which require complicated preparations and manipulations before they can be applied. Raman imaging can overcome problems resulting from the limited stability, bleaching, and restricted accessibility of external markers [28]. Band assignments of Raman spectra of human cell lines are presented in Table 2, according to different publications in the literature.

\section{Applications of Vibrational Spectroscopy in Stem Cell Researches}

\subsection{Stem Cells Analyzed by FTIR Spectroscopy and Microspectroscopy}

\subsubsection{Embryonic Stem Cells Applications}

Embryonic stem (ES) cells by their in vitro differentiation potential into specific phenotypes have an important role in the development of stem cell therapy, tissue engineering, and regenerative medicine. FTIR microspectroscopy coupled with PCA and unsupervised hierarchical cluster analysis (UHCA) were used to determine specific markers of murine ES cell differentiation toward neural cell types in the study of [30]. Main spectral differences were observed in lipid- and protein-related bands. Significant increases in the area of lipid bands from $\mathrm{CH}_{3}$ and $\mathrm{CH}_{2}$ stretching vibrations, respectively, at 2959, 2923 and $2852 \mathrm{~cm}^{-1}$ were suggested as an expression of membrane glycerophospholipids responsible for 
Table 2: Raman spectroscopy band assignments of human cells [5-8].

\begin{tabular}{|c|c|}
\hline $\begin{array}{l}\text { Wavenumber } \\
\left(\mathrm{cm}^{-1}\right)\end{array}$ & Assignment \\
\hline 3070 & Amide $\mathrm{B}(\mathrm{CNH}$ bend $)$ \\
\hline 2960 & $\begin{array}{l}\mathrm{CH}_{3} \text { stretch (antisymmetric) due to methyl terminal of membrane } \\
\text { phospholipids }\end{array}$ \\
\hline 2936 & $\mathrm{CH}_{3}$ stretch \\
\hline 2928 & $\begin{array}{l}\mathrm{CH}_{2} \text { antisymmetric stretch of Methylene group of membrane phos- } \\
\text { pholipids }\end{array}$ \\
\hline 2886 & $\begin{array}{l}\mathrm{CH}_{2} \text { stretch (symmetric) due to methylene groups of membrane phos- } \\
\text { pholipids }\end{array}$ \\
\hline 2854 & $\mathrm{CH}_{2}$ stretch \\
\hline 2739 & $\mathrm{CH}$ stretch \\
\hline 1736 & $\mathrm{C}=\mathrm{O}$ stretch \\
\hline 1667,1640 & $\begin{array}{l}\text { Amide I (protein) } \mathrm{C}=\mathrm{O} \text { stretching of amide coupled to } \mathrm{NH}_{2} \text { in-plane } \\
\text { bending }\end{array}$ \\
\hline 1657,1659 & $\mathrm{C}=\mathrm{C}$ stretch (lipids), Amide I ( $\alpha$-helix, protein) \\
\hline 1611 & Tyr (aromatics) \\
\hline 1566 & Phe, Trp (phenyl, aromatics) \\
\hline 1550 & Amide II absorption due to $\mathrm{N}-\mathrm{H}$ bending coupled to a $\mathrm{C}-\mathrm{N}$ stretch \\
\hline 1509 & $\mathrm{C}=\mathrm{C}$ stretch (aromatics) \\
\hline 1452 & $\mathrm{CH}_{2}$ stretch deformation of methylene group (lipids) \\
\hline 1439 & $\mathrm{CH}_{2}$ deformation \\
\hline 1420 & $\mathrm{CH}_{3}$ asymmetric stretching (lipids, aromatics) \\
\hline 1397 & $\mathrm{CH}_{3}$ bending due to methyl bond in the membrane \\
\hline 1382 & COO- symmetric stretching \\
\hline 1367 & $\mathrm{CH}_{3}$ symmetric stretching \\
\hline 1336 & Adenine, Phenylalanine, $\mathrm{CH}$ deformation \\
\hline 1304 & Lipids $\mathrm{CH}_{2}$ twist, protein amide III band, adenine, cytosine \\
\hline 1267 & Amide III ( $\alpha$-helix, protein) \\
\hline 1250 & Amide III ( $\beta$-sheet, protein) \\
\hline 1235 & Antisymmetric phosphate stretching \\
\hline 1206 & $\mathrm{C}-\mathrm{C}$ stretch, $\mathrm{C}-\mathrm{H}$ bending \\
\hline 1165 & $\mathrm{C}-\mathrm{O}$ stretch, $\mathrm{COH}$ bending \\
\hline 1130 & $\mathrm{C}-\mathrm{C}$ asymmetric stretching \\
\hline $1100,1094,1081$ & $\mathrm{PO}_{2}{ }^{-}$symmetric stretching (nucleic acids) \\
\hline 1065 & Chain $\mathrm{C}-\mathrm{C}$ \\
\hline 1056 & RNA ribose $\mathrm{C}-\mathrm{O}$ vibration \\
\hline 1003 & Phenylalanine (ring-breathing) \\
\hline 967 & $\mathrm{C}-\mathrm{C}$ and $\mathrm{C}-\mathrm{N}$ stretch $\mathrm{PO}_{3}{ }^{2-}$ stretching (DNA) \\
\hline
\end{tabular}


Table 2: Continued.

\begin{tabular}{ll}
\hline $\begin{array}{l}\text { Wavenumber } \\
\left(\mathrm{cm}^{-1}\right)\end{array}$ & Assignment \\
\hline 957 & $\mathrm{CH}_{3}$ deformation (lipid, protein) \\
936 & $\mathrm{C}-\mathrm{C}$ residue $\alpha$-helix \\
921 & $\mathrm{C}-\mathrm{C}$ stretch proline \\
898 & $\mathrm{C}-\mathrm{C}$ stretch residue \\
870 & $\mathrm{C}-\mathrm{DNA}$ \\
853 & Ring breathing Tyr-C-C stretch proline \\
828,833 & Out of plane breathing Tyr; $\mathrm{PO}_{2}{ }^{-}$asymmetric stretching, DNA (B- \\
807 & form) \\
786 & A-DNA \\
746 & DNA-RNA $\left(\mathrm{PO}_{2}{ }^{-}\right)$symmetric stretching \\
727 & Thymine \\
\hline
\end{tabular}

neural cell differentiation and signal transduction. Important increases in $\alpha$-helix protein secondary structures appeared in differentiated cells, while there was a decrease in $\beta$-sheet protein secondary structures. These changes explained by an the increased expression of $\alpha$-helix-rich proteins of the cytoskeleton, as tubulin and actin, and important for the establishment of neural structure and function (Figure 1).

The study of Heraud and colleageus [31] examined the efficacy of FTIR spectroscopy to distinguish mesoderm and ectoderm committed cells from undifferentiated hESCs. After 4-5 days of differentiation, significant variations in band shape and absorbance were observed in protein and nucleic acids-related bands of three experimental groups. The first three principal components (PCs) explained more than $90 \%$ of the variance in the 3 experimental data sets in PCA models. In all experiments hESC spectra were separated from BMP4/Act A and FGF2 spectra along PC1, whereas BMP4/Act A and FGF2 spectra were clustered separately along PC3.

FTIR microspectroscopy, which was supported by PCA-LDA analysis, was used to characterize differentiation stages of murine ESCs spontaneously $[32,33]$. Significant spectral changes appeared in the protein $\left(1700-1600 \mathrm{~cm}^{-1}\right)$ and the nucleic acid region $\left(1150-850 \mathrm{~cm}^{-1}\right) . \alpha$-helix- and $\beta$-turns-rich proteins started to be expressed in mESCs after 4 and 7 days of differentiation that can be resulted from new proteins belonging to the new phenotype of cardiomyocyte precursors during the early period (from day 0 to 14) of spontaneous differentiation. DNA and RNA content of undifferentiated cells decreased upon differentiation. The data were analyzed by the principal component and subsequent linear discriminant analyses (PCA-LDA) that enabled to segregate ESCs spectra into excellent separate clusters and to identify the most significant spectral changes.

Synchrotron FTIR microspectroscopy study of Thumanu and colleagues [34] aimed to probe the chemical composition of single hepatic progenitor cells and study their differentiation into hepatocytelike cells from mouse embryonic stem cells. The changes in the secondary structure of amide I band at $1656 \mathrm{~cm}^{-1}$ was investigated. The increase in intensity of amide I $\alpha$-helix protein secondary structure of mature hepatocyte cells was interpreted as an emergence of albumin protein during differentiation. The 


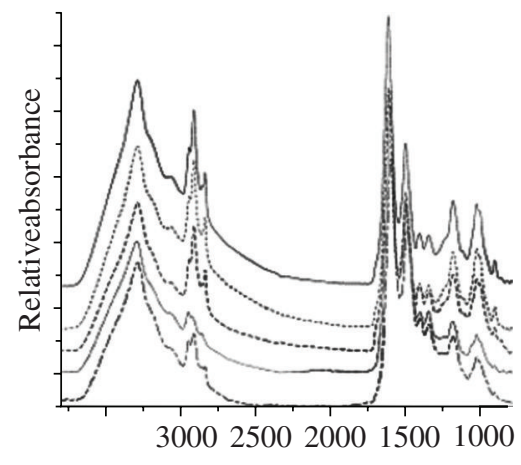

(a)

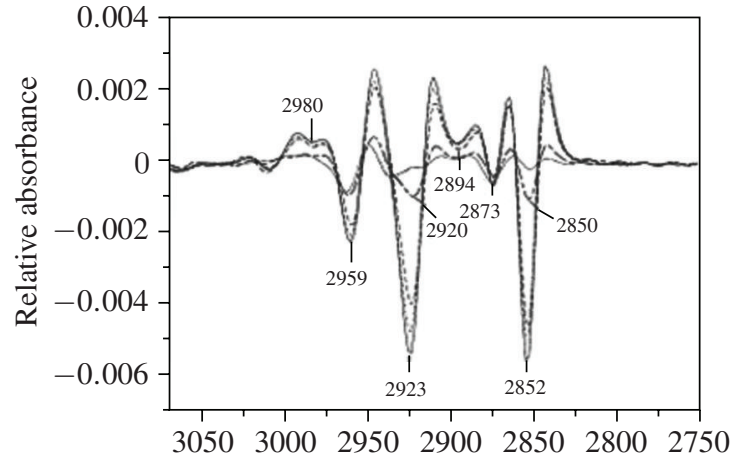

(b)

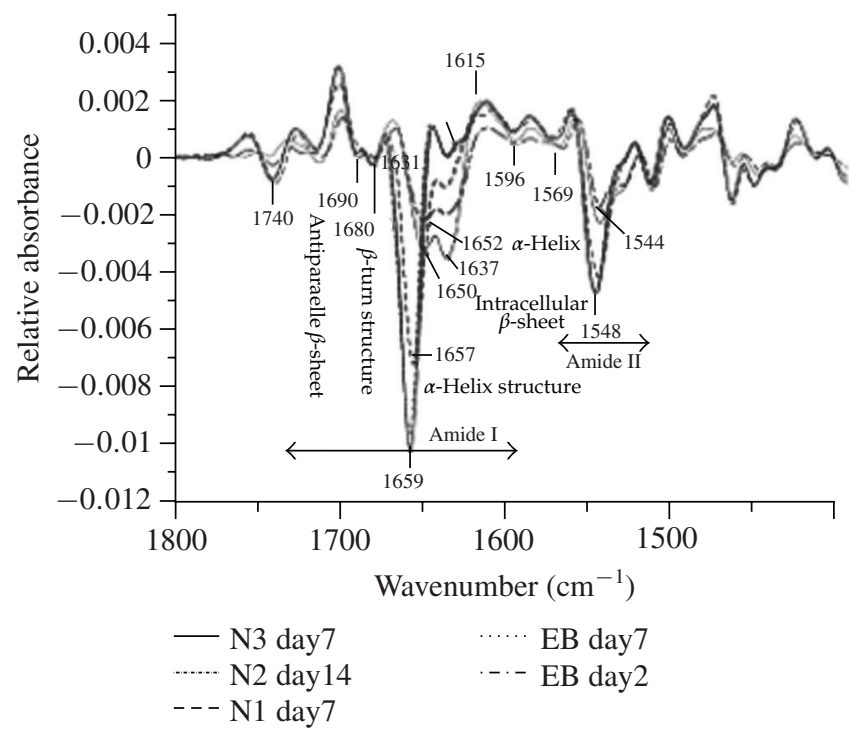

(c)

Figure 1: Average raw FTIR spectra of mESCs in different stages of differentiation towards the formation of ESNCs using FPA microspectroscopy (a). Spectra were normalized over the range of $4000-1000 \mathrm{~cm}^{-1}$. (b) shows an enlargement of the lipid spectral region from $2800 \mathrm{~cm}^{-1}$ to $3000 \mathrm{~cm}^{-1}$. (c) shows amides I and II spectral region from $1500 \mathrm{~cm}^{-1}$ to $1800 \mathrm{~cm}^{-1}$ for average second derivative spectra of mESCs in different stages of the ESNCs differentiation process after nine points of smoothing and normalization with EMSC.

frequency shift of $\beta$-sheet secondary structure of hepatic progenitor cells from $1627 \mathrm{~cm}^{-1}$ to $1641 \mathrm{~cm}^{-1}$ reflected maturation during distinct differentiation stages. The spectra of endoderm induction, hepatic progenitor cells, and mature hepatocyte-like cells were clustered separately by PCA score plot separately along PC1 and PC2 and hierarchical cluster analysis. This study and other recent studies showed that in the near future FTIR spectroscopy will be used as a complementary to existing approaches used for stem cell characterization. 


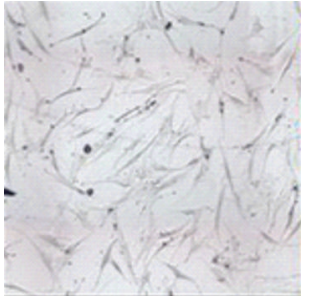

(a)

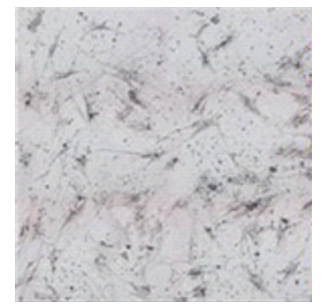

(e)

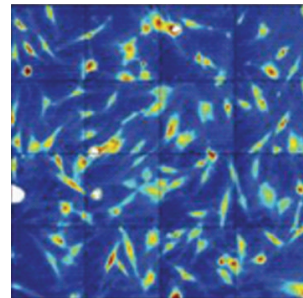

(b)

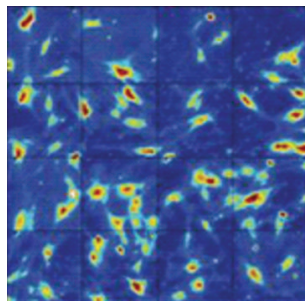

(f)

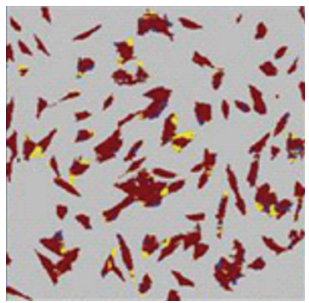

(c)

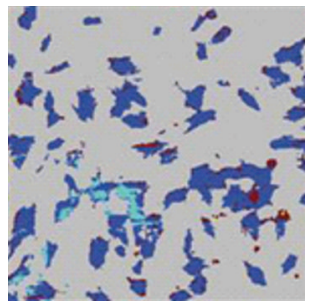

(g)

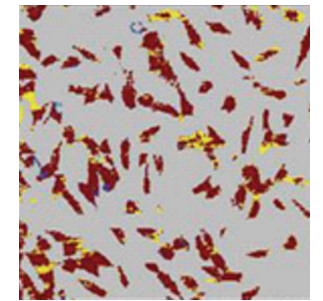

(d)

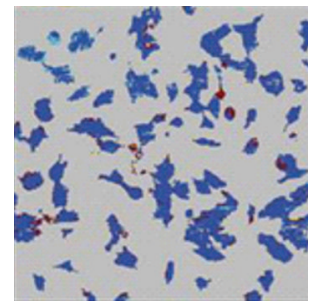

(h)

Figure 2: (a, e) Photomicrographs, (b, f) intensity distributions at $1653 \mathrm{~cm}^{-1}$, and (c, g) LDA classification of FTIR microscopic images. Plots $(\mathrm{d}, \mathrm{h})$ are independent from plots $(\mathrm{a}-\mathrm{c})$ and $(\mathrm{e}-\mathrm{g})$. The top panel shows nonstimulated hMSCs, the bottom panel osteogenic stimulated hMSCs. Low intensities near 0 are displayed as blue, high intensities up to 0.12 in red (b, f). Color code for classification results (c, d, g, h): hMSCs without stimulation (red brown), with glycogen accumulation (yellow), hMSCs with stimulation (blue), and with high expression of calcium phosphate salts (cyan).

\subsubsection{Mesenchymal Stem Cells Applications}

Mesenchymal stem cells (MSCs) with their capacity to differentiate into osteoblasts, adipocytes and chondrocytes are very attractive for transplantation therapy to promote tissue development. Therefore, definition of specific MSCs markers, identification, and characterization of lineage-specific differences are very important. In a FTIR spectroscopy study of Ishii and colleagues [35] adipose differentiation kinetics of preadipocytes and osteoblast differentiation kinetics of bone marrow mesenchymal stem cells (BM-MSCs) were examined. Absorption spectra of preadipocytes in days 3 and 5 showed increased intensity of band $1739 \mathrm{~cm}^{-1}$, that resulted from ester bonds in lipids. Characteristic strong band of calcium phosphate and hydroxyapatite crytstals (HAP) at $1030 \mathrm{~cm}^{-1}$ started to be observed in BMMSCs from the fourth day of osteogenic differentiation. Adipocyte and osteoblast differentiation of 3T3-L1 and Kusa-A1 cells was also confimed by Oil-Red O and Alizarin staining, respectively.

In an other study, differentiation states and FTIR signature of human mesenchymal stem cells (hMSCs) during osteogenic induction were identified using IR microspectroscopy by Krafft and colleagues [36]. Higher levels of glycogen were observed in nonstimulated MSCs as a result of increased band intensities at 1025,1080, and $1152 \mathrm{~cm}^{-1}$, while osteogenic stimulation caused increased intensity in band at $1100 \mathrm{~cm}^{-1}$ that corresponds an accumulation of calcium phosphate salts. Reduced levels of intensity of $\beta$-sheet secondary structure of amide I band at $1631 \mathrm{~cm}^{-1}$ can also be used a marker of osteogenic induction of stimulated cells (Figure 2). LDA classification of IR spectra distinguished the 


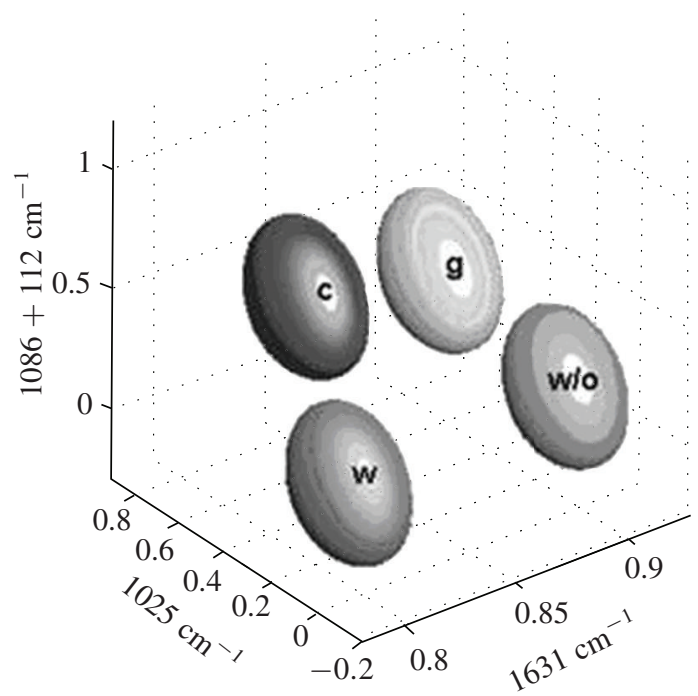

Figure 3: Three-dimensional plot of covariance ellipsoids of a LDA classification model for hMSCs with stimulation (w), without stimulation (w/o), with glycogen accumulation (g), and with high expression of calcium phosphate salts (c). The intensities of the three variates were ratioed against the intensity at $1653 \mathrm{~cm}^{-1}$.

cells in four separate groups as unstimulated, unstimulated with glycogen, stimulated, stimulated with Ca phosphate salts (Figure 3).

FTIR microspectroscopy study was performed by Walsh et al. [37] in order to discriminate the putative stem cell location from that of transit-amplifying and differentiated locations. Antisymmetric $\mathrm{PO}_{2}{ }^{-}\left(1225 \mathrm{~cm}^{-1}\right)$ and symmetric $\mathrm{PO}_{2}^{-}\left(1080 \mathrm{~cm}^{-1}\right)$ stretching vibrations of DNA significantly changed between cell groups in different locations. When IR spectral image mapping of tissue sections reconstructed according to the intensity of $1080 \mathrm{~cm}^{-1}$, both the small and large intestinal crypts showed the most intense $\mathrm{PO}_{2}{ }^{-}$signals. This means that $\mathrm{PO}_{2}{ }^{-}$can be used as a most robust marker for IR spectral of stem cells located at small and large intestinal crypts which can be used as a means of identifying stem cells.

Discriminating biomarkers of adult corneal stem cells in human cornea were examined by Bentley et al. [38], Nakamura et al. [39] and Kelly et al. [40]. Synchrotron-based radiation (SRS) FTIR microspectroscopy was used in these studies to distinguish chemical biomarkers of putative stem cells (SCs), transit-amplifying (TA) cells, or terminally-differentiated (TD) cells in human corneal epithelium. Segregation with three different cluster by PCA analysis showed that TD-cell cluster was more closely aligned to SC points than those of TA cells and the main differences were observed in DNA-RNA region including $1040 \mathrm{~cm}^{-1}$ band of $\mathrm{C}-\mathrm{O}$ vibrations, $1080 \mathrm{~cm}^{-1}$ band of symmetric phosphate stretching vibrations, $1107 \mathrm{~cm}^{-1}$ band of sugar-phosphate vibrations, and $1225 \mathrm{~cm}^{-1}$ band of antisymmetric phosphate stretching vibrations. Chemical entities associated with DNA and RNA conformation of $1080 \mathrm{~cm}^{-1}$ and $1225 \mathrm{~cm}^{-1}$ respectively, were associated with SCs, whereas proteins at $1158 \mathrm{~cm}^{-1}$ and lipids at $1728 \mathrm{~cm}^{-1}$ most distinguished TA and TD cells. Changes in RNA levels 
are important in the transition from SC to TA cells, while lipid-protein and DNA-RNA conformational changes are both important in the transition from TA cells to TD cells.

Differentiation states of human mesenchymal stem cells (hMSCs) into the chondrocytes was probed by synchroton radiation Fourier transform infrared (SR-FTIR) study of Chonanat and colleageus [41]. The major differences were observed in collagen at $1338 \mathrm{~cm}^{-1}$ (amide III band), $\mathrm{PO}_{2}{ }^{-}$stretching band at $1234 \mathrm{~cm}^{-1}$ and $\mathrm{C}-\mathrm{O}-\mathrm{C}$ stretching band at $1203 \mathrm{~cm}^{-1}$ as well as proteoglycan protein related bands at $1245 \mathrm{~cm}^{-1}$ (S-O stretching band) and 1175, 1107, 1080, 1019, $993 \mathrm{~cm}^{-1}$ (C-O-C stretching bands from carbohydrate). This indicated an increased levels of collagen and aggrecan bands in chondrocyte-induced hMSCs than those of controls, which are used as indicators for chondrocyte differentiation from hMSCs [42]. Partial least squares discriminant analysis (PLS-DA) distinguished control and chondrocyte-induced cells with $100 \%$ accuracy.

The recent study of Aksoy and colleagues [43] aimed to investigate global structural and compositional changes in bone marrow mesenchymal stem cells (BM-MSCs) of patients with beta thalassemia major $(\beta$-TM) by attenuated total reflection-Fourier transform infrared spectroscopy (ATRFTIR). The spectral results showed that there were significant increases in the area of bands, which are assigned to unsaturated and saturated lipids, located at about $3015 \mathrm{~cm}^{-1}, 2957 \mathrm{~cm}^{-1}, 2924 \mathrm{~cm}^{-1}$ and $2852 \mathrm{~cm}^{-1}$, respectively, in pretransplant BM-MSCs with respect to healthy BM-MSCs. The area amide I $\left(1639 \mathrm{~cm}^{-1}\right)$ and amide II $\left(1545 \mathrm{~cm}^{-1}\right)$ bands of proteins were significantly increased in pretranplant MSCs $(P<0.001)$ when compared to healthy control values. The increase in the band areas of antisymmetric and symmetric phosphate stretcthing vibrations located at $1234 \mathrm{~cm}^{-1}$ and $1080 \mathrm{~cm}^{-1}$ in pre-transplant BM-MSCs with respect to the control group MSCs was interpreted as an increase in nucleic acid content. This increase was supported by an increase in the area of at $925 \mathrm{~cm}^{-1}$ which is assigned as a $\mathrm{Z}$ type DNA. The global increase in the concentrations of different macromolecules in thalassemic BM-MSCs with respect to the healthy was interpreted as increased cell proliferation activity in thalassemic BM-MSCs according to healthy control BM-MSCs. However, macromolecular concentrations was decreased in the posttransplant BM-MSCs with values closer to the controls with respect to the pre-transplant samples. The decreases in the content of macromolecules, EPO and GDF15 levels and MTT proliferation assay results in post-transplant MSCs with respect to the pre-transplant MSCs were suggested as reduced abnormal ineffective erythropoiesis because of restoring effect of BMT therapy on hematopoiesis which secondarily leads to normalization of abnormal host microenvironment as well. Such a restoring effect can be used to study HSCs-MSCs dynamic interactions in bone marrow microenvironment. As can be seen from Figure 4 hierarchical cluster analysis separated distinctly control, pre- and posttransplant group BM-MSCs based on their spectral differences in the region between 3050 and $2800 \mathrm{~cm}^{-1}$.

\subsection{Stem Cells Analyzed by Raman Spectroscopy and Microspectroscopy}

\subsubsection{Embryonic Stem Cells Applications}

The first two Raman spectroscopy studies published by Notingher and colleagues [44, 45] were about in situ characterization of embryonic stem cell differentiation. The first study of Notingher et al. [44] investigated biochemical changes in murine ESCs throughout the process of differentiation by Raman microspectroscopy. The most significant differences was observed in the area of nucleic acid 


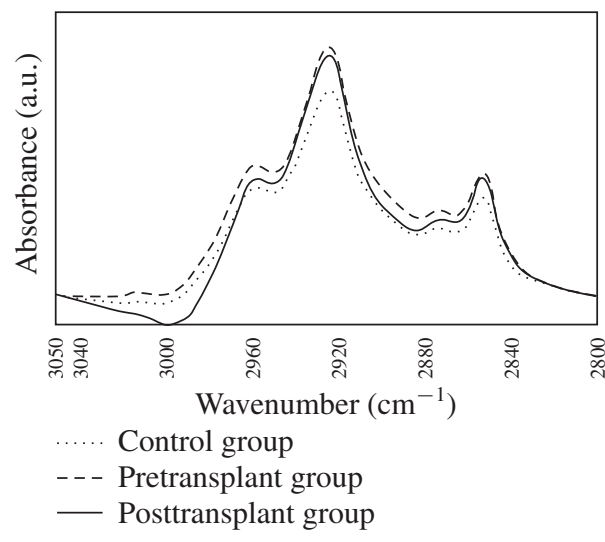

(a)

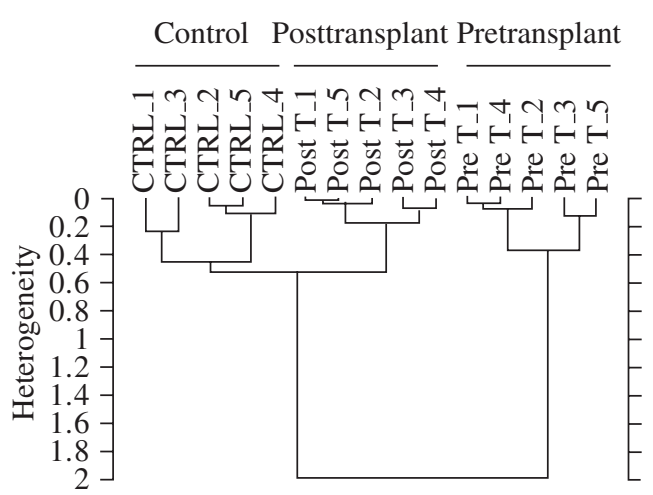

(b)

Figure 4: (a) The representative infrared spectra of control (dotted line), pre (dashed line) and post (solid line) transplant group human bone marrow mesenchymal stem cells in the $3050-2800 \mathrm{~cm}^{-1}$ region. (The deconvolved spectra were normalized with respect to the amide A band). (b) Hierarchical cluster analysis performed on the first-derivative and vector normalized spectra of control, pre- and posttransplant group BM-MSCs and resulting from Ward's algorithm. The study was conducted in the $3050-2800 \mathrm{~cm}^{-1}$ spectral region.

related Raman spectral bands during the progression of ESCs differentiation (16 days), while there were no statistically significant differences were observed between the spectra of murine ES cells in undifferentiated and early differentiation (4 days) stages. The concentration of RNA and DNA decreased significantly which implied that the decrease in synthesis of specific proteins and in the number of cells in G2/S and M phases during differentiation, respectively (Figure 5). The second publication of Notingher et al. [45] aimed to exhibit uniqunies of Raman markers of undifferentiated, spontaneously differentiated, and differentiated murine embryonic stem cells (mESCs). Although the Raman spectra of all three cell types exhibited characteristic spectral features associated with typical cellular components (e.g., nucleic acids, proteins, lipids, and carbohydrates), the main difference could be attributed to differences in RNA concentrations of cells. The Raman spectrum of RNA indicated a high concentration of RNA in mESCs compared to differentiated cells. The hierarchical cluster analysis (HCA) separated undifferentiated mESCs, spontaneous differentiated cells for 4 days, and differentiated cells via formation of embryoid bodies (EBs) as three different clusters. The results of these two studies reflected that a reduction in RNA levels can be used as marker of differentiation state of mESCs.

Another study to display structural and functional properties of early-stage differentiation of hESC-derived CMs was reported by Chan and Lieu [16]. hESCs consistently showed higher DNA and RNA intensity when compared with the more mature fetal left ventricular cardiomyocytes (FLV-CMs). These results were consistent with the mESC study described above, which showed that the stem cells exhibited higher RNA content compared to differentiated cells. A PCA-LDA analysis confirmed that the hESCs could be discriminated from the FLV-CMs. The sensitivity for accurate discrimination of hESCs, hESC-CMs, and FLV-CMs into their respective groups as stem cells or CMs, were 98, 96, and $66 \%$, respectively, when performing LDA and leave-one-out cross-validation using the first six principal components. 


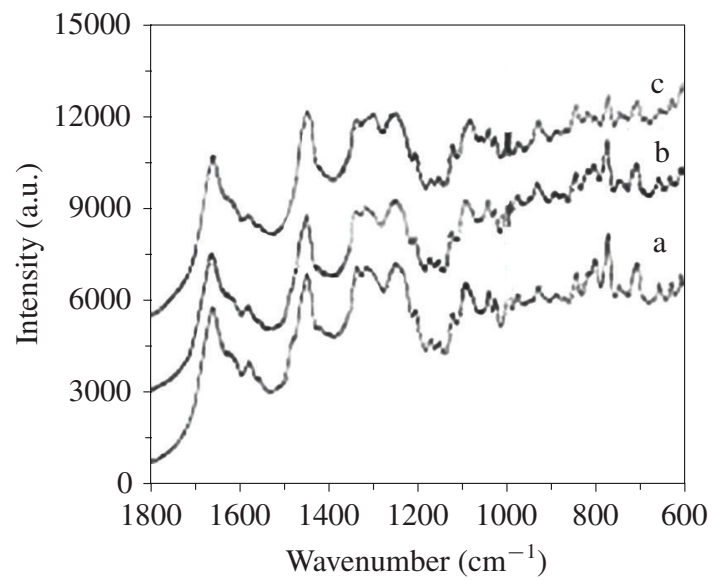

(A)

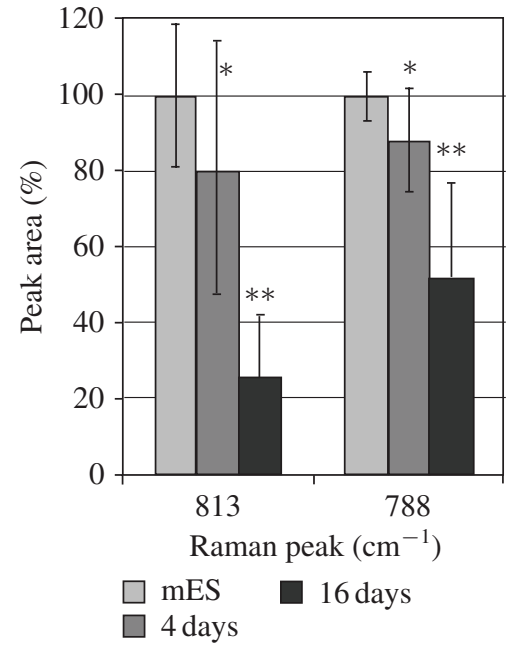

(B)

Figure 5: (A) Average Raman spectra of murine embryonic stem cells (mES) at various stages of differentiation: (a) undifferentiated, (b) 4 days differentiation, and (c) 16 days differentiation via the formation of embryoid bodies. Spectra are shifted vertically for clarity. (B) Area of Raman bands of nucleic acids (RNA $813 \mathrm{~cm}^{-1}$ and DNA $788 \mathrm{~cm}^{-1}$ ) in undifferentiated, 4 days differentiation, and 16 days differentiation via the formation of embryoid bodies $\left({ }^{*} P>0.01,{ }^{* *} P<0.01\right.$ compared to $\mathrm{mES}$ cells).

Pascut and colleagues [46] used Raman microspectroscopy (RMS) as a noninvasive method to identify human-embryonic-stem-cell-derived (hESC) cardiomyocytes (CMs) within highly heterogeneous cell populations by detecting their specific image molecular markers. The spectral results showed that glycogen band can be used as a main marker to determine CMs, while myofibril proteins have lower contribution. Principal component analysis (PCA) separated CMs from other cell populations with $>97 \%$ specificity and $>96 \%$ sensitivity, as calculated with the use of cross-validation algorithms (target $100 \%$ specificity).

In the study of Konorov et al. [19] cytochemical variations between undifferentiated and partially differentiated human embryonic stem cell (hESC) colonies were identified by Raman microspectroscopy to understand the effects of differentiation on hESCs. The protein-to-nucleic acid ratio was used as an indicator of differentiation status and it increased towards the edges of colony which implied spontaneous differentiation was higher on the edges of a colony than elsewhere. Additionally, the ratio of phospholipids to nucleic acids was increased on the edges of pluripotent and partly differentiated colonies. While glycogen to nucleic acid ratio were higher in the colony centers compared to their edges. Raman spectral results clearly showed that pluripotent and partly differentiated colonies were different from each other. In the other study of Konorov and colleagues [47] Raman spectroscopy was applied in order to measure absolute quantity of glycogen in hESCs. The results reflected that Raman microspectroscopy was faster and more reliable than existing commercial glycogen assay kits to glycogen quantification. The in situ glycogen content in hESCs and the distribution of glycogen in colony can be accurately estimated by Raman spectroscopy. This approach can be implemented to other cell types and cellular components to find real-time variations of macromolecules. 


\subsubsection{Mesenchymal Stem Cells Applications}

Osteogenic inducing effect of elk velvet antler (QEVA) extract on MSCs was examined and compared with osteogenic agent dexamethasone (Dex) by Confocal Raman Microscopy by Azrad and colleagues [48]. Hydroxyapatite (HA), amorphous calcium phosphate (ACP), and octacalcium phosphate (OCP) formation were determined by Raman spectral signals within the $950-960 \mathrm{~cm}^{-1}$ region. The Raman microspectroscopy showed that the proliferation activity of cells treated with QEVA was stronger than the cells treated with Dex or the control group, up to 4 days. Raman spectroscopy results showed that cell cultures supplemented with QEVA deposited much more HA then the cell cultures fed with Dex. Raman spectroscopy enabled to test cellular and molecular events during differentiation, which has the capacity to characterize bone formation.

Moody et al. [17] used Surface-Enhanced Raman Spectroscopy (SERS) to monitor chemical activity of human-adipose-derived stem cells (hASCs) during adipogenic differentiation. The gradual increase was detected in lipid related bands located at $775-778 \mathrm{~cm}^{-1}[49], 1362 \mathrm{~cm}^{-1}[49,50]$ and another lipid band at $1080 \mathrm{~cm}^{-1}[50,51]$ during differentiation process. The appearances of lipid bands through adipogenic differentiation was supported by an increase in the band at $1194 \mathrm{~cm}^{-1}$ which is resulted from adenine-related molecules [52]. Increase in characteristic adenosine bands is expected to be indicative of the role of cyclic AMP (cAMP) as a major component in adipogenic stimulation $[53,54]$.

In the study of Chen et al. [55], Raman microspectroscopy was applied to human umbical cord blood mesenchymal stem cells (hUC-MSCs) in different cellular states in order to find sensitive molecular vibrations that can be used to determine viability of hUC-MSCs. The intensity decrease of the band at $1342 \mathrm{~cm}^{-1}$ which is attributed from $\mathrm{C}-\mathrm{H}$ deformation in proteins reflects degradation of proteins. The intensity increase of the bands at 877 and $744 \mathrm{~cm}^{-1}$, which result, respectively, from $\mathrm{C}-\mathrm{H}$ deformation in proteins, $\mathrm{C}-\mathrm{C}$ symmetric stretching in lipids, and $\mathrm{C}=\mathrm{O}$ out-of-the-plane bending in Thymine means the structural modification of lipids and the destruction of base-base stacking interactions in DNA. These intensity changes reflected low viability that is related with the alterations of the secondary structures of proteins, the degradation of proteins, the structural modification of lipids, and the destruction of base-base stacking interactions in DNA.

McManus et al. [56] reported the formation of bone-like apatite mineral during osteogenic differentiation of human mesenchymal stem cells (hMSCs). Confocal Raman spectra of nonosteogenic and induced hMSCs showed that the main changes occurred in phosphate groups $\left(950-970 \mathrm{~cm}^{-1}\right.$, $1030 \mathrm{~cm}^{-1}$ and $1070 \mathrm{~cm}^{-1}$ ). After 14 days of differentiation a crystalline nonsubstituted apatite minerals started to be observed and the other substituted minerals such as amorphous apatite and a carbonate were formed. These minerals can be used as a specific Raman markers to identify cristalinity and degree of mineralisation of hMSCs when they differentiate into osteoblasts.

Pudlas et al. [57] tested the employment of Raman spectroscopy to separate human fibroblasts and bone marrow mesenchymal stem cells (BM-MSCs). The analysis of mean spectra of fingerprint region $\left(1800 \mathrm{~cm}^{-1}-600 \mathrm{~cm}^{-1}\right)$ showed that stem cells had higher metabolic activity and proliferative capacity. Principal component analysis (PCA) discriminated Raman spectra of human fibroblast and BM-MSCs along the PC1 axis with $64 \%$ variance and with $12 \%$ variance along the PC2 as given in Figure 6. This study clarified convenience of Raman spectroscopy for the rapid detection of fibroblastic contaminations in BM-MSC cultures. 


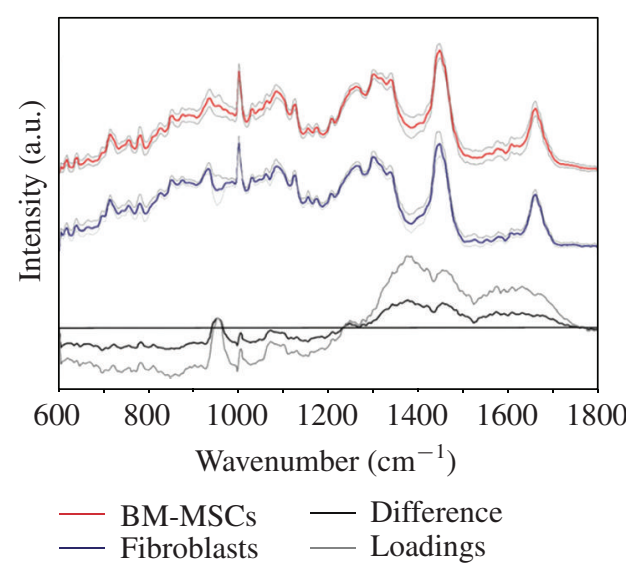

(a)

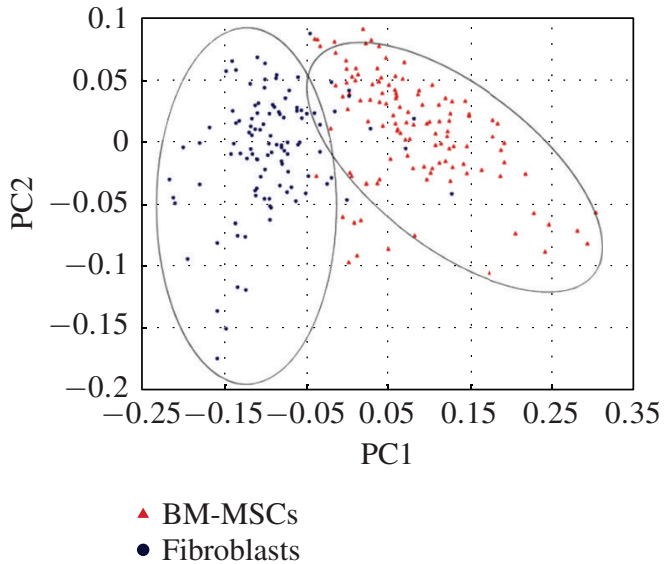

(b)

Figure 6: (a) Mean Raman spectra obtained from human BM-MSCs (red; $n=122$ ) and fibroblasts (blue; $n=109$ ) displayed in the fingerprint range from $600 \mathrm{~cm}^{-1}$ to $1800 \mathrm{~cm}^{-1}$. All data are detected as relative intensities in arbitrary units (a.u.). The difference spectrum (black line) is obtained by subtracting the spectrum of human BM-MSCs from the spectrum of fibroblasts. Loading values (grey line) are plotted for the first principal component (PC1), defined by the PCA plot. (b) The PCA dot plot shows two clearly distinguishable cell populations depicted as red (BM-MSCs) and blue (fibroblasts) clusters.

\section{Conclusion}

This paper reviewed the main vibrational spectroscopy techniques that are used for noninvasive monitoring and characterization of embryonic and mesenchymal stem cells and their differentiated progenies. Existing studies in the literature used Raman and FTIR spectroscopy and imaging techniques to analyze the differences between nondifferentiated stem cells and differentiated cells in both murine [44] and human embryonic stem cells [16] and also human mesenchymal stem cells [56]. Studies showed that main differences between matured and differentiated stem cells were associated with the spectral signatures of nucleic acids and protein components of different stem cell types. These results were mainly related with the relative quantities of untranslated mRNA, DNA, and protein of stem cells. Stem cells use up the pool of mRNA in order to synthesize of new, specific proteins of specific cell lineages during their differentiation process. Meanwhile, conformational changes in DNA reflect changes in chromatin structure and higher nuclear-to-cytoplasmic ratio that happens during cell differentiation. When mesenchymal stem cells were differentiated into osteoblasts, they display a clear band(s) attributed to mineral composition $[16,35]$. It can be clearly concluded from the studies in the literature that vibrational spectroscopy techniques supply valuable information about unique biochemical nature and structure of stem cells that can both fingerprint cell types and provide an indications of overall changes in macromolecular composition of stem cells in a label-free, noninvasive, nondestructive manner. 


\section{References}

[1] C. M. Krishna, G. Kegelaer, I. Adt et al., "Characterisation of uterine sarcoma cell lines exhibiting MDR phenotype by vibrational spectroscopy," Biochimica et Biophysica Acta, vol. 1726, no. 2, pp. 160-167, 2005.

[2] A. Nijssen, T. C. Bakker Schut, F. Heule et al., "Discriminating basal cell carcinoma from its surrounding tissue by raman spectroscopy," Journal of Investigative Dermatology, vol. 119, no. 1, pp. 64-69, 2002.

[3] A. Synytsya, P. Alexa, J. Besserer et al., "Raman spectroscopy of tissue samples irradiated by protons," International Journal of Radiation Biology, vol. 80, no. 8, pp. 581-591, 2004.

[4] G. J. Puppels, H. S. Garritsen, G. M. Segers-Nolten, F. F. de Mul, and J. Greve, "Raman microspectroscopic approach to the study of human granulocytes," Biophysical Journal, vol. 60, no. 5, pp. 1046-1056, 1991.

[5] N. Gault and J. L. Lefaix, "Infrared microspectroscopic characteristics of radiation-induced apoptosis in human lymphocytes," Radiation Research, vol. 160, no. 2, pp. 238-250, 2003.

[6] N. Gault, J. L. Poncy, and J. L. Lefaix, "Radiaton-induced apoptosis: a new approach by means of infrared microspectroscopy," Canadian Journal of Physiology and Pharmacology, vol. 82, no. 1, pp. 38-49, 2004.

[7] N. Gault, O. Rigaud, J. L. Poncy, and J. L. Lefaix, "Infrared microspectroscopy study of $\gamma$-irradiated and $\mathrm{H}_{2} \mathrm{O}_{2}$-treated human cells," International Journal of Radiation Biology, vol. 81, no. 10, pp. 767-779, 2005.

[8] S. Zellmer, I. Zimmermann, C. Selle, B. Sternberg, W. Pohle, and J. Lasch, "Physicochemical characterisation of human stratum corneum lipid liposomes," Chemistry and Physics of Lipids, vol. 94, no. 1, pp. 97-108, 1998.

[9] E. B. Kelly, Stem Cells, Green Wood Press, Wesport, Conn, USA, 2007.

[10] J. Panno, Stem Cell Research: Medical Applications and Ethical Controversy, Facts On File, New York, NY, USA, 2005.

[11] K. Turksen, Human Embryonic Stem Cell Protocols, Humana Press, New Jersey, NJ, USA, 2006.

[12] S. Kadereit, Adult stem cells, Ph.D. thesis, International Society for Stem Cell Research Publication.

[13] R. S. Tuan, G. Boland, and R. Tuli, "Adult mesenchymal stem cells and cell-based tissue engineering," Arthritis Research and Therapy, vol. 5, no. 1, pp. 32-45, 2003.

[14] R. J. Deans and A. B. Moseley, "Mesenchymal stem cells: biology and potential clinical uses," Experimental Hematology, vol. 28, no. 8, pp. 875-884, 2000.

[15] J. K. Pijanka, D. Kumar, T. Dale et al., "Vibrational spectroscopy differentiates between multipotent and pluripotent stem cells," Analyst, vol. 135, no. 12, pp. 3126-3132, 2010.

[16] J. W. Chan and D. K. Lieu, "Label-free biochemical characterization of stem cells using vibrational spectroscopy," Journal of Biophotonics, vol. 2, no. 11, pp. 656-668, 2009.

[17] B. Moody, C. M. Haslauer, E. Kirk, A. Kannan, E. G. Loboa, and G. S. McCarty, "In situ monitoring of adipogenesis with human-adipose-derived stem cells using surface-enhanced raman spectroscopy," Applied Spectroscopy, vol. 64, no. 11, pp. 1227-1233, 2010.

[18] P. Heraud and M. J. Tobin, "The emergence of biospectroscopy in stem cell research," Stem Cell Research, vol. 3, no. 1, pp. 12-14, 2009.

[19] S. O. Konorov, H. G. Schulze, J. M. Piret, S. A. Aparicio, R. F. B. Turner, and M. W. Blades, "Raman microscopy-based cytochemical investigations of potential niche-forming inhomogeneities present in human embryonic stem cell colonies," Applied Spectroscopy, vol. 65, no. 9, pp. 1009-1016, 2011. 
[20] A. Downes, R. Mouras, and A. Elfick, "Optical spectroscopy for noninvasive monitoring of stem cell differentiation," Journal of Biomedicine \& Biotechnology, vol. 2010, Article ID 101864, 10 pages, 2010.

[21] G. Srinivasan, Vibrational Spectroscopic Imaging for Biomedical Applications, The McGraw-Hill Companies, 2010.

[22] C. Berthomieu and R. Hienerwadel, "Fourier transform infrared (FTIR) spectroscopy," Photosynthesis Research, vol. 101, no. 2-3, pp. 157-170, 2009.

[23] P. J. Larkin, Infrared and Raman Spectroscopy: Principles and Spectral Interpretation, Elsevier, San Diego, Calif, USA, 2011.

[24] T. Hirschfeld, "Subsurface layer studies by attenuated total reflection Fourier transform spectroscopy," Applied Spectroscopy, vol. 31, no. 4, pp. 289-292, 1977.

[25] M. K. Kuimova, K. L. A. Chan, and S. G. Kazarian, "Chemical imaging of live cancer cells in the natural aqueous environment," Applied Spectroscopy, vol. 63, no. 2, pp. 164-171, 2009.

[26] C. Krafft and V. Sergo, "Biomedical applications of Raman and infrared spectroscopy to diagnose tissues," Spectroscopy, vol. 20, no. 5-6, pp. 195-218, 2006.

[27] S. Y. Lin, M. J. Li, and W. T. Cheng, "FT-IR and Raman vibrational microspectroscopies used for spectral biodiagnosis of human tissues," Spectroscopy, vol. 21, no. 1, pp. 1-30, 2007.

[28] C. Krafft, U. Neugebauer, and J. Popp, Vibrational Spectroscopic Imaging for Biomedical Applications, The McGraw-Hill Companies, 2010.

[29] R. J. Swain and M. M. Stevens, "Raman microspectroscopy for non-invasive biochemical analysis of single cells," Biochemical Society Transactions, vol. 35, no. 3, pp. 544-549, 2007.

[30] W. Tanthanuch, K. Thumanu, C. Lorthongpanich, R. Parnpai, and P. Heraud, "Neural differentiation of mouse embryonic stem cells studied by FTIR spectroscopy," Journal of Molecular Structure, vol. 967, no. 1-3, pp. 189-195, 2010.

[31] P. Heraud, E. S. Ng, S. Caine et al., "Fourier transform infrared microspectroscopy identifies early lineage commitment in differentiating human embryonic stem cells," Stem Cell Research, vol. 4, no. 2, pp. 140-147, 2010.

[32] D. Ami, T. Neri, A. Natalello et al., "Embryonic stem cell differentiation studied by FT-IR spectroscopy," Biochimica et Biophysica Acta, vol. 1783, no. 1, pp. 98-106, 2008.

[33] D. Ami, P. Mereghetti, A. Natalello, and S. M. Doglia, "Fourier transform infrared microspectroscopy as a tool for embryonic stem cell studies," in Stem Cells in Clinic and Research, InTech, 2011.

[34] K. Thumanu, W. Tanthanuch, D. Ye et al., "Spectroscopic signature of mouse embryonic stem cellderived hepatocytes using synchrotron Fourier transform infrared microspectroscopy," Journal of Biomedical Optics, vol. 16, no. 5, Article ID 057005, 2011.

[35] K. Ishii, A. Kimura, T. Kushibiki, and K. Awazu, "Fourier transform infrared spectroscopic analysis of cell differentiation," Progress in Biomedical Optics and Imaging-Proceedings of SPIE, vol. 6439, Article ID 64390I, 2007.

[36] C. Krafft, R. Salzer, S. Seitz, C. Ern, and M. Schieker, "Differentiation of individual human mesenchymal stem cells probed by FTIR microscopic imaging," Analyst, vol. 132, no. 7, pp. 647-653, 2007.

[37] M. J. Walsh, T. G. Fellous, A. Hammiche et al., "Fourier transform infrared microspectroscopy identifies symmetric $\mathrm{PO}_{2}$ - modifications as a marker of the putative stem cell region of human intestinal crypts," Stem Cells, vol. 26, no. 1, pp. 108-118, 2008.

[38] A. J. Bentley, T. Nakamura, A. Hammiche et al., "Characterization of human corneal stem cells by synchrotron infrared micro-spectroscopy," Molecular Vision, vol. 13, pp. 237-242, 2007. 
[39] T. Nakamura, J. G. Kelly, J. Trevisan et al., "Microspectroscopy of spectral biomarkers associated with human corneal stem cells," Molecular Vision, vol. 16, pp. 359-368, 2010.

[40] J. G. Kelly, T. Nakamura, S. Kinoshita, N. J. Fullwood, and F. L. Martin, "Evidence for a stem-cell lineage in corneal squamous cell carcinoma using synchrotron-based Fourier-transform infrared microspectroscopy and multivariate analysis," Analyst, vol. 135, no. 12, pp. 3120-3125, 2010.

[41] C. Chonanant, N. Jearanaikoon, C. Leelayuwat et al., "Characterisation of chondrogenic differentiation of human mesenchymal stem cells using synchrotron FTIR microspectroscopy," Analyst, vol. 136, no. 12, pp. 2542-2551, 2011.

[42] N. P. Camacho, P. West, P. A. Torzilli, and R. Mendelsohn, "FTIR microscopic imaging of collagen and proteoglycan in bovine cartilage," Biopolymers, vol. 62, no. 1, pp. 1-8, 2001.

[43] C. Aksoy, A. Guliyev, E. Kilic, D. Uckan, and F. Severcan, "Bone marrow mesenchymal stem cells in patients with beta thalassemia major: molecular analyses with attenuated total reflection-fourier transform infrared (atr-ftir) spectroscopy study as a novel method," Stem Cells and Development. In press.

[44] I. Notingher, I. Bisson, J. M. Polak, and L. L. Hench, "In situ spectroscopic study of nucleic acids in differentiating embryonic stem cells," Vibrational Spectroscopy, vol. 35, no. 1-2, pp. 199-203, 2004.

[45] I. Notingher, I. Bisson, A. E. Bishop, W. L. Randle, J. M. P. Polak, and L. L. Hench, "In situ spectral monitoring of mRNA translation in embryonic stem cells during differentiation in vitro," Analytical Chemistry, vol. 76, no. 11, pp. 3185-3193, 2004.

[46] F. C. Pascut, H. T. Goh, N. Welch, L. D. Buttery, C. Denning, and I. Notingher, "Noninvasive detection and imaging of molecular markers in live cardiomyocytes derived from human embryonic stem cells," Biophysical Journal, vol. 100, no. 1, pp. 251-259, 2011.

[47] S. O. Konorov, H. G. Schulze, C. G. Atkins et al., "Absolute quantification of intracellular glycogen content in human embryonic stem cells with Raman microspectroscopy," Analytical Chemistry, vol. 83, no. 16, pp. 6254-6258, 2011.

[48] E. Azrad, D. Zahor, R. Vago et al., "Probing the effect of an extract of elk velvet antler powder on mesenchymal stem cells using Raman microspectroscopy: enhanced differentiation toward osteogenic fate," Journal of Raman Spectroscopy, vol. 37, no. 4, pp. 480-486, 2006.

[49] K. Fujita, S. Ishitobi, K. Hamada et al., "Time-resolved observation of surface-enhanced Raman scattering from gold nanoparticles during transport through a living cell," Journal of Biomedical Optics, vol. 14, no. 2, Article ID 024038, 2009.

[50] R. E. Kast, G. K. Serhatkulu, A. Cao et al., "Raman spectroscopy can differentiate malignant tumors from normal breast tissue and detect early neoplastic changes in a mouse model," Biopolymers, vol. 89, no. 3, pp. 235-241, 2008.

[51] S. Koljenović, L. P. Choo-Smith, T. C. B. Schut, J. M. Kros, H. J. van den Berge, and G. J. Puppels, "Discriminating vital tumor from necrotic tissue in human glioblastoma tissue samples by Raman spectroscopy," Laboratory Investigation, vol. 82, no. 10, pp. 1265-1277, 2002.

[52] C. Otto, T. J. J. van den Tweel, F. F. M. de Mul, and J. Greve, "Surface-enhanced Raman spectroscopy of DNA bases," Raman Spectroscopy, vol. 17, pp. 289-298, 1986.

[53] D. C. Yang, H. J. Tsay, S. Y. Lin et al., "cAMP/PKA regulates osteogenesis, adipogenesis and ratio of RANKL/OPG mRNA expression in mesenchymal stem cells by suppressing leptin," PLoS ONE, vol. 3, no. 2, Article ID e1540, 2008.

[54] C. N. Bennett, S. E. Ross, K. A. Longo et al., "Regulation of Wnt signaling during adipogenesis," Journal of Biological Chemistry, vol. 277, no. 34, pp. 30998-31004, 2002.

[55] P. Chen, F. Zhang, L. Lin, H. Bai et al., "Raman spectroscopy for noninvasive monitoring of umbilical cord mesenchymal stem cells viability transitions," in Stem Cells in Clinic and Research, InTech, 2011. 
[56] L. L. McManus, G. A. Burke, M. M. McCafferty et al., "Raman spectroscopic monitoring of the osteogenic differentiation of human mesenchymal stem cells," Analyst, vol. 136, no. 12, pp. 24712481, 2011.

[57] M. Pudlas, D. A. C. Berrio, M. Votteler et al., "Non-contact discrimination of human bone marrowderived mesenchymal stem cells and fibroblasts using Raman spectroscopy," Medical Laser Application, vol. 26, no. 3, pp. 119-125, 2011. 


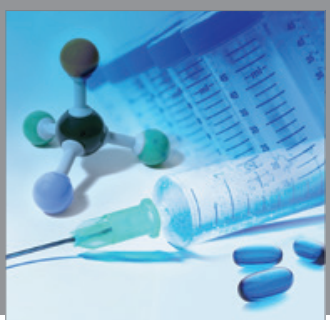

International Journal of

Medicinal Chemistry

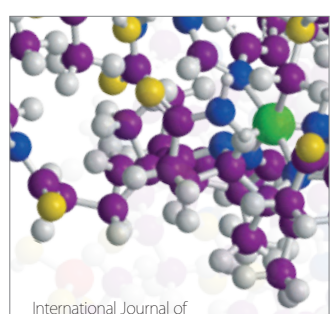

Carbohydrate Chemistry

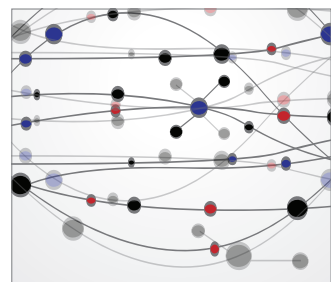

The Scientific World Journal
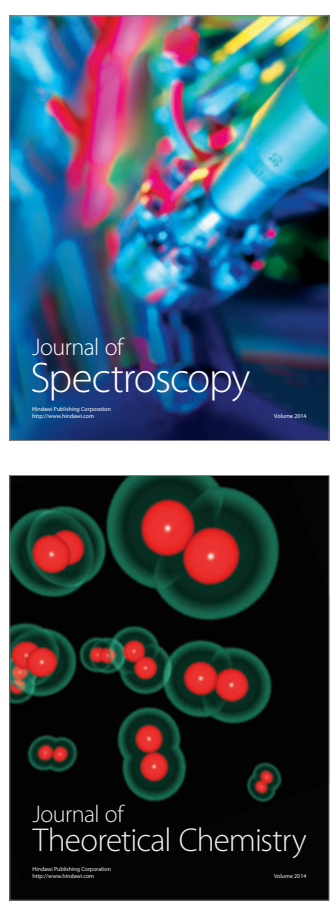
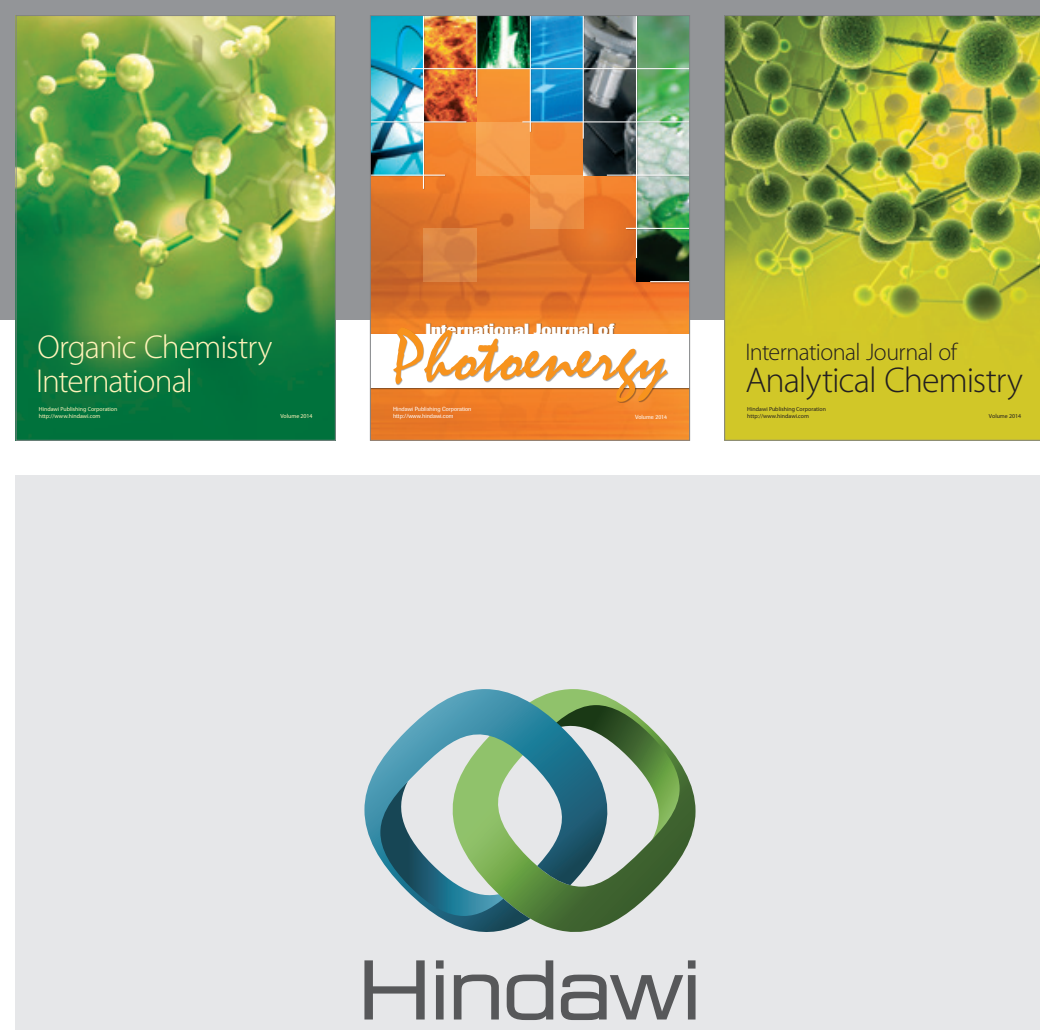

Submit your manuscripts at

http://www.hindawi.com
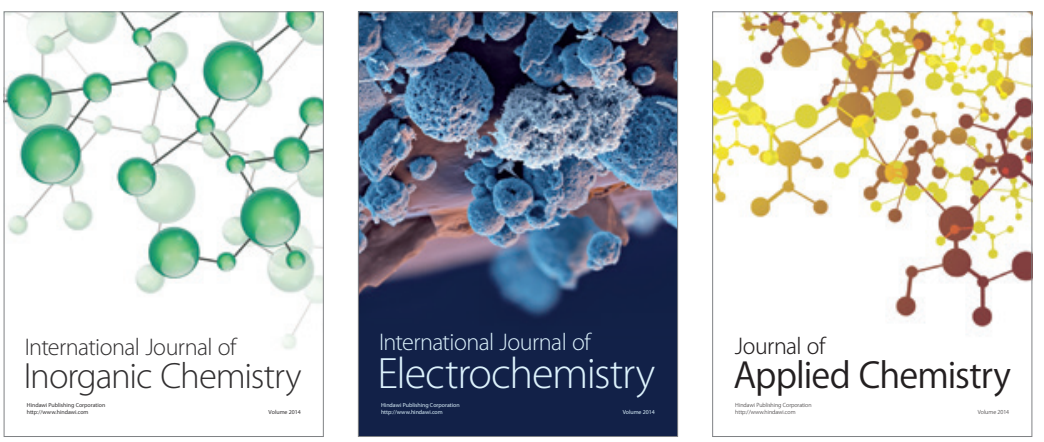

Journal of

Applied Chemistry
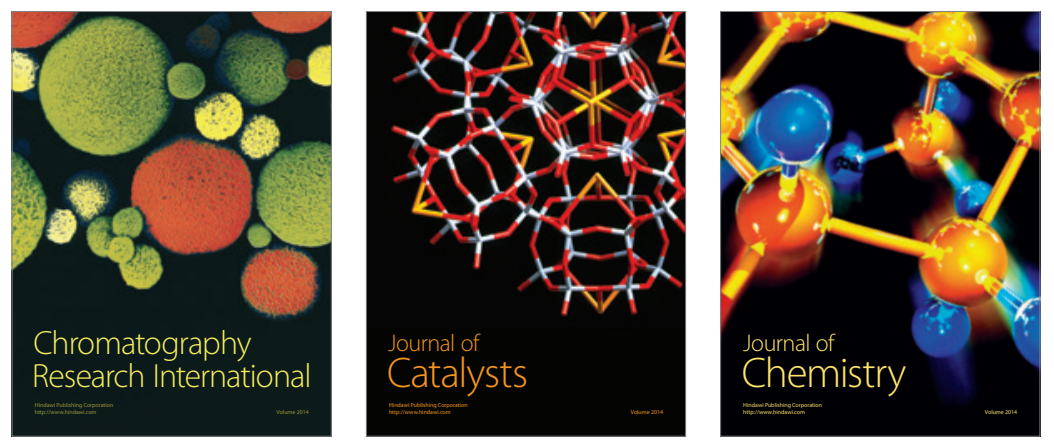
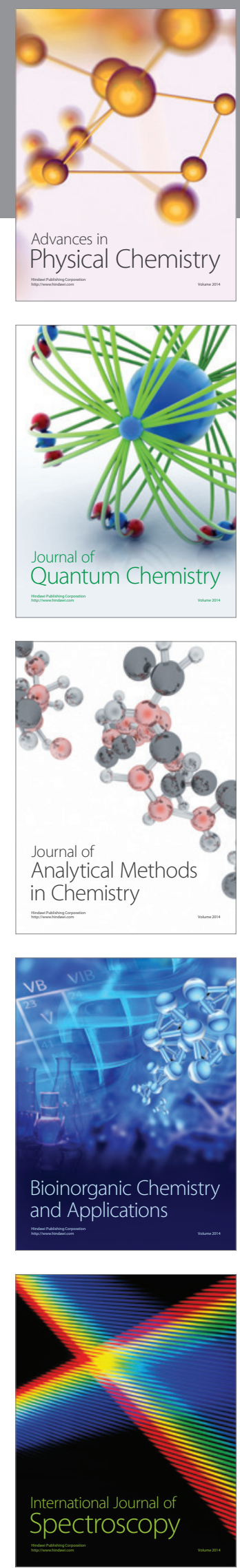